Acta Universitatis Nicolai Copernici • Pedagogika XXXIV/2/2017

Nauki Humanistyczno-Społeczne • Zeszyt 440

DOI: http://dx.doi.org/10.12775/AUNC_PED.2017.023

Piotr Krakowiak

Uniwersytet Mikołaja Kopernika

\title{
Katarzyna Błaszczuk, Dorota Rynkowska, Problemy społeczne i opiekuńcze seniorów i ich rodzin. Studium socjologiczne na przykładzie opinii pracowników socjalnych,
}

Wydawnictwo Uniwersytetu Rzeszowskiego, Rzeszów 2016

$\mathrm{D}$ obrze się stało, że zbadano opinie pracowników socjalnych odnośnie do opieki senioralnej, którą należy wpisać do rosnącego ciągle zadania „opieki nad osobami u kresu życia” w przestrzeni ochrony zdrowia, pomocy społecznej i funkcjonowania naszych lokalnych społeczności i całego społeczeństwa ${ }^{1}$. Zbudowana na etosie solidarności międzyludzkiej opieka paliatywno-hospicyjna w Polsce ${ }^{2}$ obejmuje opieką głównie chorych nowotworowych i ich rodziny, ale pilną potrzebą społeczną jest włączenie $\mathrm{w}$ tę opiekę pracowników socjalnych, wolontariuszy i istniejące podmioty ekonomii społecznej. Recenzowana praca składa się z rozpoczynającego ją przesłania „Od Autorów”, wstępu, pięciu rozdziałów, opracowanych na podstawie badań tekstów źródłowych i badania ankietowego przeprowadzonego wśród pracowników socjalnych. Praca kończy się podsumowaniem, a po nim jest zakończenie oraz spisów tabel, rysunków, bibliografii i aneksów.

1 Por. P. Krakowiak, Wolontariat w opiec u kresu życia, Toruń 2012.

2 Por. A. Janowicz, P. Krakowiak, A. Stolarczyk (red.), Solidarni. Opieka paliatywno-hospicyjna $w$ Polsce, Gdańsk 2015. 
Autorki we wprowadzeniu zauważają, iż problematyka starzenia się, starości i opieki stanowi w Europie i w Polsce przedmiot coraz bardziej ożywionych społecznych dyskusji i badań naukowych, będąc obecna zarówno w naukach medycznych, społecznych, jak i w dyskursie ekonomicznym i politycznym. Starzenie się społeczeństw jest już faktem w wielu krajach współczesnej Europy, a demograficzne wskaźniki wyraźnie wskazują na zmiany w tej dziedzinie w naszym kraju³. Wśród badań przeprowadzonych wśród seniorów w Polsce w przestrzeni nauk społecznych można dostrzec u osób starszych troskę o zdrowie fizyczne i pielęgnację osób zależnych, co jest domeną ochrony zdrowia i pedagogiki opiekuńczej. Ale przestrzenią zdominowaną przez pomoc społeczną i pracę socjalną jest podtrzymywanie relacji rodzinnych i społecznych, pomoc seniorom w aktywnym uczestnictwie w różnych obszarach życia, a także ich zabezpieczenie materialne. Wyzwaniem, o którym informują polscy seniorzy, są także problemy dyskryminacji ze względu na wiek i stosunek społeczeństwa do osób starych i niesamodzielnych.

Należy zgodzić się z autorkami recenzowanej publikacji, że

celem nowoczesnej polityki społecznej wobec osób starszych jest m.in. próba dbałości o jakość ich życia w poszczególnych fazach starości i skuteczne reagowanie na specyficzne potrzeby seniorów. Człowiek starszy powinien mieć możliwość zaspokajania potrzeb i funkcjonowania w bliskim mu otoczeniu, ponieważ sytuacja społeczna, zdrowotna i ekonomiczna w znaczący sposób wpływa na proces starzenia się. Zależy to przede wszystkim od środowiska, głównie rodzinnego, jego własnego stosunku do starości, a także oferowanej pomocy. Obecnie w europejskich modelach pomocy seniorom odchodzi się od instytucjonalnej formy usług na rzecz pozostawiania osoby starszej w dotychczasowym środowisku, przy wsparciu rodziny i środowiskowych form pomocy. Rodzina jest dla każdego człowieka podstawowym środowiskiem życia ${ }^{4}$.

3 GUS, Prognoza ludności na lata 2014-2050, Warszawa 2014, publikacja dostępna online: www. gus. stat. gov. pl, dostęp: październik 2017.

4 Por. K. Błaszczuk, D. Rynkowska, Problemy społeczne i opiekuńcze seniorów $i$ ich rodzin. Studium socjologiczne na przykładzie opinii pracowników socjalnych, Rzeszów 2016, s. 5. 
Wymaga to reorganizacji systemu opieki, lepszej pomocy geriatrycznej, a także stworzenia sieci instytucjonalnych placówek świadczących usługi pielęgnacyjno-opiekuńczych, mogących wspierać rodziny. Recenzowana publikacja jest studium socjologicznym tego zjawiska w opinii pracowników socjalnych.

Wstęp omawianej monografia ukazuje wybrane problemy związane $\mathrm{z}$ funkcjonowaniem osób starszych $\mathrm{w}$ rodzinie i społeczeństwie. W niektórych swoich elementach jest on powtórzeniem treści zawartych we wprowadzeniu, co może być konsekwencją dwuautorskiego dzieła i opisu tych samych problemów, choć z różnymi akcentami. Tezą wartą przytoczenia w całości są słowa:

Zjawisko starzenia się społeczeństwa przy braku odnawialności pokoleń stanowi zagrożenie dla rozwoju gospodarczego kraju i poziomu życia ludzi. Próba „ratowania” sytuacji demograficznej w Polsce poprzez wydłużenie aktywności zawodowej ludzi starszych i przesunięcie granicy wieku emerytalnego dla obu płci, może okazać się wyłącznie doraźną formą rozwiązania kwestii zatrudnienia i świadczeń emerytalno-rentowych ${ }^{5}$.

Obok powtórzenia części informacji, wstęp spełnia właściwie swoją funkcję, ukazując rozdziały w kluczu ich autorek, co stanie się podstawą niniejszej recenzji.

Autorką rozdziałów I i II jest Dorota Rynkowska, a rozdział pt. Hierarchia potrzeb $w \dot{z} y c i u$ jednostki ukazuje znaczenie potrzeb w cyklu życia człowieka. Termin „potrzeba” omówiono za Januszem Reykowskim, a choć wspomniano, że w literaturze przedmiotu istniej „wiele koncepcji potrzeb człowieka, bardziej lub mniej rozbudowanych w zależności od przyjętych sposobów klasyfikowania, to omówiono tylko najpowszechniej znaną koncepcję hierarchii potrzeb Maslowa". Tak skrótowe potraktowanie tych zagadnień można uznać za zasadne jedynie ze względu na podręcznikowy czy poradnikowy charakter tej publikacji, podobnie jak ukazanie osoby ludzkiej w egzystencjalnym cyklu, począwszy od dzieciństwa i młodości, poprzez dorosłość, aż do będącej przedmiotem szczególnej uwagi tej publikacji starość. Tę część rozpoczyna ciekawa

\footnotetext{
5 Tamże.
} 
tabela potrzeb wieku senioralnego, a także typologia i analiza potrzeb przytaczana za Zofią Szarotą ${ }^{6}$. Pierwszy rozdział kończy odniesienie do Listu do osób w podeszłym wieku autorstwa Jana Pawła II7. Choć rozdział jest na dużym poziomie ogólności i opiera się na kilku cytowanych publikacjach, w sposób zadawalający przedstawia definicje, podział i znaczenie potrzeb w cyklu życia człowieka, uwzględniając ich hierarchię w poszczególnych okresach rozwojowych.

W drugim rozdziale, zatytułowanym „Funkcjonowanie seniora w zakresie pełnionych ról", autorka rozpoczyna rozważania od listy rodzajów aktywności seniorów, a następnie omawia ich aktywności domowo-rodzinne, pozarodzinne i aktywności społeczne oraz zawodowe. Te ostatnie zostały opisane bardziej szczegółowo, rozpoczynając od życiodajnej aktywności autorstwa Aleksandra Kamińskiego przejawiającej się w wykonywaniu pracy cenionej i użytecznej, a także w zaspokajaniu potrzeb psychofizycznych i głębszych zainteresowań wpisanych w sferę odpoczynku. Opis aktywnej starości ukazują funkcje aktywności osób starszych, które zostały opisane szeroko za Grażyną Orzechowską . Następuje po nim opis stylów życia seniorów z sześcioma podstawowymi grupami: od całkowitej bierności, przez bariery związane z niesamodzielnością, styl rodzinny, styl działkowicza, osoby zaangażowanej społecznie, styl pobożny aż po styl homocentryczny będący kombinacją stylu rodzinnego i biernego. Następnie, pisząc o formach aktywizacji osób starszych, autorka zauważa, że istnieje wiele kryteriów podziału aktywności w wieku senioralnym i rozpoczyna od omawiania aktywności kulturalno-oświatowej. Do jej najważniejszych form zalicza się: indywidualne realizacje zainteresowań i potrzeb kulturalnych, których treść jest determinowana wspomnianymi wcześniej stylami życia, a także działalność hobbystyczna i coraz częściej woluntarystyczna, realizowana głównie w wymiarze lokalnym. Autorka za Adamem A. Zychem podkreśla, że zachowanie

6 Por. Z. Szarota, Gerontologia społeczna i oświatowa-zarys problematyki, Kraków 2004.

7 Por. Jan Paweł II, List do osób w podeszłym wieku, Poznań 1999.

8 G. Orzechowska, Aktualne problemy gerontologii społecznej, Olsztyn 2001, s. 44. 
optymalnej równowagi pomiędzy aktywnością psychiczną i fizyczną człowieka jest nie tylko podstawą dobrego zdrowia i długowieczności, ale również swoistą gwarancją łagodnego wejścia w ostatnią fazę życia ludzkiego, gdyż emeryci mogą dysponować swoim czasem.

Słusznie ukazano, iż hamulcem w swobodnym funkcjonowaniu seniorów bywają często bariery finansowe, niosące ze sobą dezaktywizację, przez co życie seniorów staje się ponure. Nie uczestnicząc w życiu społecznym, kulturalnym, rodzinnymi i nie kontaktując się z innymi, stają się zagrożeni izolacją i wykluczeniem. Wśród form aktywizacji wymieniono Kluby Seniora, Uniwersytety Trzeciego Wieku (UTW) i wolontariat. W ich prezentacji oprócz informacji na dużym poziomie ogólności, mogłyby się pojawić ilustracje konkretnych działań i dobre praktyki, dostępne w publikacjach i wirtualnych raportach, publikowanych przez opisywane organizacje, jak choćby dostępne publikacje o UTW ${ }^{9}$ oraz badania tego zjawiska w przestrzeni nauk społecznych ${ }^{10}$. „Znaczenie aktywności w życiu człowieka starszego" kończy ten rozdział ukazujący różne formy aktywności seniorów w środowisku domowym i poza nim, przedstawiający przemiany we współczesnych rodzinach i ich wpływ na utratę więzi międzypokoleniowej oraz znaczenie różnych stylów życia osób starszych. Właściwym apelem na koniec tych rozważań wydają się zaczerpnięta z Hanny Dąbrowieckiej słowa:

pozytywnym elementem aktywizacji ludzi starszych jest wspieranie działania instytucji w środowisku lokalnym. Nie należy izolować tej grupy od reszty społeczeństwa. Wszystkie tego typu działania powinny być prowadzane przy współudziale seniorów. Mają oni być nie tylko adresatami czy uczestnikami, ale również współtwórcami tego typu przedsięwzięćn ${ }^{11}$.

9 Por. Standardy działania Uniwersytetów Trzeciego Wieku w Polsce, Nowy Sącz 2012, dostępne onlnie: http://www. federacjautw. pl/putw/images/glowna/standardy. pdf, dostęp: październik 2017.

10 Z. Hasińska, E. Tracz, Rola uniwersytetów trzeciego wieku w aktywnym starzeniu się, „Nauki Społeczne”, nr 1(7), 2013, s. 93-102, www. dbc. wroc. pl/Content/24426/Hasinska_Tracz_Rola_uniwersytetow_trzeciego_wieku_w_aktywnym. pdf, dostęp: październik $201 \overline{7}$.

11 H. Dąbrowiecka, Pomóc wyjść z cienia. Uwagi o aktywności osób starszych, „Niebieska Linia”, nr 6/47 (2006), s. 22-24. 
Dwa kolejne rozdziały publikacji są autorstwa Katarzyny Błaszczuk, a pierwszy z nich: Samodzielność seniora $w$ życiu codziennym jest poświęcony opisowi sposobów funkcjonowania osoby starszej w codziennym życiu. Rozpoczyna go analiza czynników warunkujących samodzielność w wieku geriatrycznym, a przydatne dla odbiorców z obszaru nauk społecznych jest ukazanie wieloczynnikowych uwarunkowań zmian prowadzących do ograniczenia samodzielności i funkcjonowania społecznego seniora. Przejrzyście zaprezentowane zostały w tabeli przygotowanej za Zofią Kawczyńską-Butrym zmiany i zaburzenia w sferze funkcjonowania układu nerwowego ${ }^{12}$, a po nich lista ograniczeń samodzielności w funkcjonowaniu codziennym seniora z zaburzeniami neurologicznymi. Za Agnieszką Borzym przedstawiono w kolejnej tabeli informacje dotyczące metod poprawiających funkcjonowanie na poziomie aktywności poznawczej seniorów z demencjami. Ważną i pomocną uwagą, zwłaszcza w sprawowaniu opieki domowej są słowa: „Przedstawione formy terapii są prostymi metodami, które nie wymagają pomocy specjalisty i mogą być wykorzystywane w codziennym życiu przez opiekunów rodzinnych"13. Tę część kończy praktyczne wskazanie dla rodzin i opiekunów:

W przypadku postępującej demencji, należy zapewnić seniorowi aktywność poprzez wykonywanie prostszych czynności (porządkowanie rzeczy, układanie kanapek na talerzu, zwijanie wełny, obieranie ziemniaków, ścielenie łóżka, zmywanie naczyń, ścieranie kurzu). Jeśli rodzina wyręcza osobę starszą $\mathrm{w}$ obowiązkach domowych, traci ona kontakt $\mathrm{z}$ otoczeniem, nie pamięta o czynnościach dnia codziennego i wykazuje niechęć do podejmowania jakiegokolwiek wysiłku. Zagraża to skróceniem okresu samodzielnego funkcjonowania seniora ${ }^{14}$.

Kolejna część rozdziału to omówienie aktywności seniorów niewymagającej pomocy osób trzecich, a dobrym sposobem wizualizacji tej problematyki jest tabela, w której przedstawiono ocenę wydolności

12 Z. Kawczyńska-Butrym, Wyzwania rodziny: zdrowie, choroba, niepetnosprawność, starość, Lublin 2008.

13 K. Błaszczuk, D. Rynkowska, dz. cyt., s. 47.

14 Tamże, s. 48. 
człowieka według Karnofsky’s Scale. W kolejnej części dotyczącej przeżywania strat przez seniorów i ich wpływu na funkcjonowanie zabrakło odniesień do literatury przedmiotu, co warto byłoby uzupełnić, bo jest to ważny element, choć pewnie nie do końca pasujący do tej części rozdziału. Mógłby on zostać przedstawiony jako jedna z barier dla samodzielności seniora, w kolejnej części rozdziału. Przeżywanie strat jest jedną z barier subiektywnych w starości i mogłoby zostać dopisane do ich wykazu ze s. 52. Zbyt zdawkowo zostały omówione bariery obiektywne, a braki odniesień bibliograficznych z ukazaniem istniejących dobrych praktyk nie pozwolą zainteresowanym czytelnikom na pogłębienie omawianych problemów. Słuszne są konkluzje przedstawione przez autorkę:

Niekwestionowane znaczenie dla samodzielnego funkcjonowania człowieka w codziennym życiu ma stan zdrowia. Brak choroby, dysfunkcji i niepełnosprawności nie jest jednak wyłącznym warunkiem radzenia sobie z czynnościami dnia codziennego. Najważniejsze jest przełamywanie barier wewnętrznych i zewnętrznych utrudniających człowiekowi aktywność w zakresie zaspokajania codziennych potrzeb i radzenia sobie z problemami. Przy wsparciu społecznym i pomocy organizowanej ze strony członków rodziny, znajomych, sąsiadów lub profesjonalistów, można stopniowo pokonywać trudności i podwyższać poziom możliwości samodzielnego decydowania o jakości swojego życia ${ }^{15}$.

Czwarty rozdział dotyczy zależności seniorów od opieki i od początku odwołuje się do opublikowanej w poprzednim rozdziale skali Karnofsky'ego i na wstępie ogólnie omawia kwestie funkcjonowania seniorów z problemami demencyjnymi oraz z ograniczeniami wieku starczego bez tych schorzeń. Utrata zdolności do samoopieki, czyli dbałości o swoje zdrowie, życie i rozwój wymaga oceny zdolności do samoopieki seniora, co zostało osadzone w znanej w literaturze przedmiotu teorii Orem, obejmującej trzy wzajemnie ze sobą powiązane składowe: teorię samoopieki, teorię deficytu samoopieki oraz teorię systemów pielęgnowania. Przydatne dla czytelników z nauk społecznych i opiekunów rodzinnych jest opracowanie własne tych zagadnień

15 Tamże, s. 53-54. 
w formie tabeli, opierającej się na omawianych kategoriach potrzeb w zakresie samoopieki według Doretei Orem ${ }^{16}$. Następnie omówiono deficyty $\mathrm{w}$ opiece i metody asystowania w samoopiece, przedstawiając je w czytelny i zrozumiały sposób w opracowanej przez autorkę tabeli. Ważną rolę edukacji zdrowotnej opisanej w kolejnej części rozdziału odgrywa kształtowanie umiejętności życia z chorobą i/lub niepełnosprawnością oraz przygotowanie do samoopieki oznaczającej niezależność w codziennym funkcjonowaniu i radzenie sobie w nowej sytuacji życiowej. Kolejna część omawia ocenę zapotrzebowania na opiekę, a oprócz medycznego wywiadu i badania lekarskiego wymagana jest od opiekunów umiejętność oceny parametrów geriatrycznych przy zastosowaniu odpowiednich skali i testów. Wykaz parametrów geriatrycznych ocenianych w skalach i testach zawiera kolejna tabela z ośmioma najbardziej znanymi skalami używanymi w ochronie zdrowia i pomocy społecznej, umówionymi szczegółowo w aneksie recenzowanej publikacji.

W kolejnej części omówiono część modelów, skupiono się zwłaszcza na GERONTE przedstawionym szczegółowo w kolejnej tabeli. Słuszne ze względu na charakter publikacji jest zakończenie tego rozdziału stwierdzeniem:

Wymienione skale i testy oceny aktywności i zapotrzebowania na opiekę nie wyczerpują możliwości zastosowania narzędzi diagnostycznych, ponieważ wiele jest stosowanych mierników oceny przez specjalistów z różnych dziedzin działalności terapeutycznej i opiekuńczo-pielęgnacyjnej, udostępnionych do wykorzystania przez wszystkie instytucje, a także opracowanych do użytku wewnętrznego przez przedstawicieli określonej instytucji/zakładu z zastrzeżeniem praw autorskich ${ }^{17}$.

W kolejnej części omówione zostały dysfunkcje w sferze zdrowia, a poziom ogólności i brak odniesień do literatury przedmiotu mogą być zrozumiałe jedynie w świetle zdania, iż z uwagi na przedmiot niniej-

16 Por. L. Płaszewska-Żywko, Teoria Dorothei Orem, w: Modele opieki pielęgniarskiej nad chorym dorosłym, pod red. M. Kózki, L. Płaszewskiej-Żywko, Warszawa 2010, s. 17.

17 K. Błaszczuk, D. Rynkowska, dz. cyt., s. 66. 
szego opracowania nie będą opisywane wszystkie zmiany prowadzące do zaburzeń i schorzeń w podeszłym wieku. Ukazane przykłady są tylko przybliżeniem problematyki zdrowotnej, która jest szeroko poruszana w literaturze gerontologicznej i opracowaniach naukowych z dziedziny medycyny. Z pewnością jednak wskazanie w bibliografii kilku głównych podręczników mogłoby być pomocą dla pracowników socjalnych czy opiekunów rodzinnych, pragnących pogłębić wiedzę w tym zakresie. W kolejnych podrozdziałach na dużym poziomie ogólności omówiono czynniki socjoekonomiczne bez żadnego odniesienia do literatury przedmiotu. Lepiej opracowany został podrozdział pt. Wizerunek seniora $w$ opiniach członków rodziny, a będąca opracowaniem własnym tabela z wykazem sfer aktywności i problemów osób starszych związanych ze sferami funkcjonowania jest cenną częścią tego rozdziału. Podsumowując, można stwierdzić, iż zagadnienia dotyczące zdolności człowieka do samoopieki oraz zapotrzebowania osoby starszej na usługi opiekuńcze i pielęgnacyjne, przedstawione w oparciu o skale służące do oceny ograniczeń w sferze psychofizycznej spowodowanych dysfunkcjami zdrowotnymi, oraz czynniki wpływające na społeczny wizerunek seniora zostały omówione w sposób właściwy dla tego rodzaju publikacji.

Rozdział piąty jest współautorstwa Katarzyny Błaszczuk i Doroty Rynkowskiej, a nosi tytuł: Analiza sytuacji życiowej seniorów na podstawie przeprowadzonych badań. Rozpoczyna go opis autorskiego kwestionariusza ankiety, składającej się z 44 pytań, a następnie analiza danych demograficznych uczestników badań. Kolejne strony zostały poświęcone analizie wyników badania ankietowego przeprowadzonego wśród czynnych zawodowo pracowników socjalnych z terenu województwa lubelskiego. Uzyskane dane przedstawione zostały w czytelnej dla odbiorców formie prezentacji graficznych. Po omówieniu sytuacji zdrowotnej badanych, w kolejnej części przedstawiono relacje osób starszych z członkami rodzin, w tym szczególnie utrzymanie kontaktów interpersonalnych, co po raz kolejny zilustrowano, by uczynić bardziej przyswajalnymi wyniki badań własnych. W formie tabel przedstawiono następnie formy aktywności domowej i pozadomowej oraz problemy zgłaszane pracownikom socjalnym przez członków rodzin podopiecznych w zakresie sprawowania opieki i relacji 
interpersonalnych. Te badania mogą być pomocne zarówno dla praktyków realizujących opiekę, jak i studentów oraz badaczy, podobnie jak wykorzystane wcześniej badania związane z wolontariatem hospicyjnym $^{18}$.

Podsumowanie to tytuł części będącej analizą badań własnych, gdyż rozpoczyna go informacja o celach badania i pytaniach badawczych, stąd sugestia rozważenia zmiany tytułu tej części publikacji na Analiza badań własnych. Ukazano w tej części wyniki badań, z których możemy się dowiedzieć, że w opinii pracowników socjalnych połowa badanych seniorów oceniała swoją sytuację materialną jako „średnią”, a tylko jedna trzecia uznała, że ma dobrą sytuację materialną, natomiast jedna piąta określiła swoją sytuację materialną jako „złą”. W opisie wniosków z badań ukazano, że „najczęściej zgłaszanymi problemami przez członków rodzin osób starszych były zaburzone relacje interpersonalne"19, a słusznym zabiegiem autorek było wymienienie ich, co może być pomocą zarówno dla profesjonalistów, jak i opiekunów nieformalnych. Autorki konkludują, iż na podstawie przeprowadzonej analizy wyników badania można wskazać obszary najczęściej występujących problemów społecznych i opiekuńczych stanowiących wyzwanie dla pracowników socjalnych podczas planowania pracy z osobami starszymi i ich rodzinami. Ich zdaniem pozwoli to na ustalenie hierarchii potrzeb w środowisku życia i aktywności seniorów w celu przełamywania barier międzypokoleniowych i stereotypów stygmatyzujących osoby starsze, które zagrażają wykluczeniem tych osób ze środowiska społecznego. Właściwe są też sugestie i rekomendacje kończące tę część recenzowanego dzieła, choć przydałoby się w nich odniesienie do literatury przedmiotu: polskiej ${ }^{20}$ i obcej ${ }^{21}$.

18 P. Krakowiak, Społeczne i edukacyjne funkcje wolontariatu hospicyjnego. Badania $w$ działaniu 2002-2010, Gdańsk 2012.

19 K. Błaszczuk, D. Rynkowska, dz. cyt., s. 94.

20 P. Krakowiak, Wolontariat $w$ opiece u kresu życia.

21 A. Janowicz, P. Krakowiak, A. Stolarczyk, In Solidarity. Hospice-palliative care In Poland, Gdańsk 2015. The role of social workers in palliative, end of life and bereavement care, www.apcsw. org.uk/resources/social-work-role-eol. pdf, dostęp: październik 2017. 
Zakończenie jest lakonicznym powtórzeniem zamysłu i planu recenzowanej publikacji, przedstawianym już we wstępie, ale być może pomocnym dla tych, którzy od lektury tych dwóch części rozpoczynają ocenę zawartości dzieła. Pomimo zgłaszanych zastrzeżeń co do ogólności przekazu niektórych treści, przyjmując poradnikowy i podręcznikowy charakter tej publikacji, zakończę za autorkami stwierdzeniem z tej części pracy, że „publikacja może stanowić wskazówkę do wypracowania przez przedstawicieli służb pomocowych i opiekuńczych własnych standardów i sposobów rozwiązania zaobserwowanych lub zgłaszanych problemów osób starszych i ich rodzin"22. Ciekawa i wnosząca nowe informacje dla lokalnej społeczności Lubelszczyzny jest przeprowadzona analiza badania własnego, a przedstawione w ostatnim rozdziale odpowiedzi na pytania badawcze mogą pomóc pracownikom służb społecznych w opracowaniu diagnozy problemów w środowisku lokalnym i lepszej współpracy ochrony zdrowia, pomocy społecznej i rodzin w trosce o seniorów. Praca posiada wielostronicowe spisy tabel, bibliografii i aneksy, w których zamieszczono skale i testy służące do oceny funkcjonowania osób starszych, stosowane w celu określenia indywidualnego zapotrzebowania na czynności opiekuńcze oraz możliwości samoopieki, o której można by napisać więcej w tym dziele ${ }^{23}$.

Autorki wyraziły we wstępie „nadzieję, że monografia nie tylko spotka się z zainteresowaniem czytelników, ale może pomóc osobom pracującym w obszarze opieki nad seniorami w planowaniu efektywnych działań pozwalających podopiecznym/pacjentom geriatrycznym znaleźć optymalne rozwiązania problemów utrudniających utrzymanie dobrej kondycji psychofizycznej i pogarszających jakość ich życia"24. Recenzowana publikacja jest próbą zasypywania przepaści pomiędzy ochroną zdrowia i pomocą społeczną, a także formalnymi i nieformalnymi opiekunami osób przewlekle chorych i niesamodzielnych w opiece domowej, co było sugerowane w literaturze przedmiotu jako pilna

22 K. Błaszczuk, D. Rynkowska, dz. cyt., s. 97.

23 Por. A. Wlazło, J. Leszek, Samoopieka osób starszych w kontekście psychologii zdrowia. Założenia teoretyczne, „Psychogeriatria Polska” nr 5(2003), s. 123-128.

24 K. Błaszczuk, D. Rynkowska, dz. cyt., s. 6. 
potrzeba $^{25}$. Podstawowe i przystępnym językiem napisane treści dotyczące różnych aspektów opieki nad seniorami sprawiają, że ta książka może być zarówno pomocą dla studentów nauk społecznych, szczególnie pedagogiki społecznej, opiekuńczej i pracy socjalnej, jak i cennym źródłem wiedzy dla opiekunów rodzinnych osób starszych i niesamodzielnych. Potrzeba kolejnych publikacji, zawierających praktyczną wiedzę i badania potrzeb seniorów, które wiążą się ze zmianami demograficznymi i z brakiem dostatecznej współpracy międzysektorowej oraz integracji i koordynacji opieki w środowisku lokalnym.

25 Por. P. Krakowiak, Wolontariat $w$ opiece u kresu życia. 